\title{
Killer-Cell Immunoglobulin-Like Receptor
}

National Cancer Institute

\section{Source}

National Cancer Institute. Killer-Cell Immunoglobulin-Like Receptor. NCI Thesaurus. Code C104678.

A family of cell surface proteins found on natural killer cells that both interact with MHC class I molecules and modulate natural killer cell-mediated cytotoxicity. 